\title{
The Trends of Al-Balqa' Applied University Students towards Jordanian Woman's Political Participation in Parliamentary Elections
}

\author{
Mohamed Nur Hussein Bani Irsheid ${ }^{1}$, Nader Ibrahim Mohammed Bani Nasur ${ }^{1}$, Abeer Rashid Olimat $^{1} \&$ Wadah \\ Soud Al-Adwan ${ }^{1}$ \\ ${ }^{1}$ Princess Rahma College, Al-Balqa Applied University, Jordan \\ Correspondence: Nader Ibrahim Mohammed Bani Nasur, Princess Rahma College, Al-Balqa Applied University, \\ Jordan. E-mail: naderalsalem@yahoo.com
}

Received: April 13, 2019

doi:10.5539/jpl.v12n4p127
Accepted: September 24, 2019 Online Published: November 28, 2019

URL: https://doi.org/10.5539/jpl.v12n4p127

\begin{abstract}
This study aimed at investigating Al Balqa' Applied University Students attitude towards Jordanian woman's political participation in parliamentary elections. Researchers used a questionnaire in order to obtain needed data for the study. The sample of the study consisted of (1327) male and female students (589 male) and (738 female) students.
\end{abstract}

The study posed the following questions:

1) What are the attitudes of Al-Balqa Applied University students towards woman's participation in politics in Jordan?

2) Are there any statistically significant differences due to gender, college education level, and residency variables?

In order to achieve the study's objectives, researchers used various statistical analyses, such as averages account, triple $\mathrm{t}$ - test, and Shiva posteriori comparisons. The study reached the following results:

1) Students attitude towards woman's political participation in all questionnaire items were medium with means of (3.68).

2) The paragraph that read "woman better able to understand the status of woman" comes in the first place with means of (4.35), and the paragraph that reads "woman's participation in parliamentary elections increases herself confidence" came in second place with means of (4.17), and The paragraph that reads I support the election of a woman who has high education and culture came in third place with means of (4.14), while the paragraph that reads "woman is well qualified physically and intellectually for political participation" came in the last place, with means of (3.06).

There is statistically significant differences due to gender variable in favor of female student.

There is no statistically significant difference due to residency; there are statistically significant differences due to study level in favor of fourth year students.

There are no statistically significant differences due to college type. Recommendations are expressed.

Keywords: Jordanian woman, Al-Balq' applied university, political participation, student attitudes, parliamentary elections

\section{Introduction}

The political participation of a woman is a central part in the democratic process, an indication of the level of progress made in the political process, a condition of citizenship and entrench human rights and her role in public and private life. (Al-Anzi, 2008). The Hashemite Kingdom of Jordan has been one of the most countries interested in woman's issues and political participation in order to integrate her into the political process, there are many Jordanian laws that give a woman political rights, including the law of elections to the House of Representatives, which gives woman the right to vote and stand for election in 1982. (Al-Anzi, 2008). The Jordanian Constitution indicates the principle of equality between man and woman, and pledges to protect it during the work and ensures her of personal freedom and gives her the right to political participation. (Tahboub, 
2003). Given the importance of a woman's participation in the political process in which she constitutes one-half of the society, and has a key role in the development process. This study came to discuss this vital and important subject for Jordanian woman and society as a whole.

\subsection{Problem of the Study}

Woman in the Jordanian society is almost one-half of the population, her large participation in elections, and despite the progress made in the field of education, employment and access to decision-making positions, however, she is still unable to reach clearly and concretely places of decision-making. Therefore, this study came to identify the trends of Al-Balqa' Applied University students towards woman's participation in the parliamentary elections.

\subsection{The Importance of the Study}

This study highlights the importance of the trends of Al-Balqa' Applied University students towards Woman's political participation in the parliamentary elections. The results of this study could enhance the role of woman's participation in the parliamentary elections more than it is now.

Also, it highlights the importance of the study to be the first work to deal with the university student attitudes. The results of this study could also be as a guide to other studies to deal with the issue in more details and in-depth in order to find out the obstacles that prevent woman's access to parliament without the presence of the woman's quota.

\subsection{Objectives of the Study and Its Questions}

This study aimed to detect the trends of Al-Balqa' AppliedUniversity students towards the political participation of Jordanian woman in parliamentary elections.To achieve this objective the study posed the following questions:-

1) What are the trends of the Al-Balqa' AppliedUniversity students on Jordanian woman's participation in the Jordanian elections?

2) Are there statistically significant differences depending on the following variables (sex, academic level, place of residence)?

\subsection{Determinants of the Study}

Spatial determinants: This study was limited to Al-Balqa Applied University Students enrolled in the second semester of the academic year 2012/2013.

Determinants temporal: This study was limited to the second semester of the academic year 2012/2013. Operational Definitions:

Political participation: Rush, (1992) defines political participation , as the individual's involvement in different levels of activities in the political system. This study intends to examine Jordanian woman's political participation in the parliamentary elections, both as candidates and as voters, which can be identified through the paragraphs of the resolution prepared for this purpose.

Trends: The trends in this study is the outcome of responses subjects (Al-Balqa' AppliedUniversity students) on the paragraphs of the resolution prepared for the collection of information and data on woman's political participation in political action.

Students: The Al-Balqa' Applied University Students enrolled in the second semester of the academic year 2012/2013 and who will answer the questionnaire items.

\section{Theoretical Framework and Previous Studies}

This chapter included both sides of the theoretical framework and previous studies.

\subsection{Theoretical Framework}

Woman's political participation goes back to several reasons, the most important is the growing role that started to play in various fields of life in the present day. This role has grown after a woman going out of the house to seek knowledge and work, also have increased the importance of this role at the social and economic levels. Women have engaged in various activities of the most important political activity where the women have become involved in political activities through the institutions of civil society in the community, such as trade unions, parties and municipal councils, and the Chamber of Deputies, and the importance of political participation reflect the political awareness enjoyed by citizens in the country, through their perception of power in the state and the nature of the relationship with them. (Ashour, 2003). 


\subsection{Definition of Political Participation}

Philip Pro (1998) Defined it, as the collective sum of the activities carried out by the citizens and shall give them an impact on the functioning of the political system, but it must be the citizens who are performers for these activities.

Rush (1992) defines it as the political participation which is the individual's involvement in different levels of activities in the political system. Naqshband (2001) defines, the political participation, as it includes the legal activities by the citizens, which aims to influence the selection of people in the government or the procedures and actions taken by the government (Naqshbandi, 2001).

\subsection{Factors Influencing the Political Participation}

1) Social Factors: as sex, place of residence, and age.

2) Economic factors: the level of income.

3) Cultural factors: the level of education, and caste loyalty.

4) Political culture and political socialization, and these are of the most important factors that affect political participation, as defined by (Powell \& Almond), as "consisting of beliefs, values and skills present in the entire community, as well as the tendencies of the formation, which can be found in separate parts of the ethnic groups. The importance of the political culture lies in contributing to the formation of people's convictions to engage in political activities and the perception that can be carried by an individual for his role in society and his view of the role of others in the community. (Al-Saleh, 1997).

(Powell \& Almond), defines political culture as "consisting of beliefs, values and skills present in the entire community, as well as private and formation tendencies that can be found in separate parts of ethnicity group. The importance of political culture is that it contributes to the formation of people's convictions about the political activities and visualization that can be carried by an individual's role in society and his view of the role of others in the community.

Lipest, (1973) puts a list of factors that influencing the political participation through a study of voting in legislative elections process in the United States of America as following:

\begin{tabular}{ll}
\hline Higher Participation & Lower Participation \\
\hline Higher income & Low income \\
Higher Education & Lower Education \\
Business men & Skilled workers \\
White collar retainers & Servants \\
Men & Women \\
Government employees & Service workers \\
The age group between 35- 55 & Less than 35 \\
Married & Bachelors \\
Grain Growers commercial & Farmers \\
\hline
\end{tabular}

As for the forms of political culture Almond and Vera(,1965) defined it in three forms:

1) Limited Political Culture: This form is often prevail in tribal societies, where the leader of the tribe is Mr. obeyed, and there is no role for the others in the political participation.

2) Dependency Culture: The lack of participation by the citizen in the political decision-making process, and often this pattern prevailed in rural areas.

3) Culture participation: Here individuals involved in the decision-making process (Al-Saleh,1997).

\subsection{Previous Studies}

1) Al- Anzi Study (2008) entitled the political participation of Jordanian woman in the political action from1952-2006 aimed to analyze the reality of the political participation of Jordanian woman in political action.

The study sample included (150) women in the Amman (Jordan's capital) and the results were as follows: 
Stressing the importance of woman's political participation and her role in the political development process, thereby helping to achieve woman's targets in the national agenda set by the document we are all Jordan, also showed that woman's political participation in a combination of factors and variables that are related to civil society and the extent of this community to the process of political participation and political maturity enjoyed by the community in order to be eligible for the process of political participation, and showed that there is equality of rights between man and woman by (60.8\%), it also showed that (44.2) of the sample have shown that the media is not exposed to image positive political participation of Jordanian woman, and that the most common reasons that lead to the selection of the man as a candidate in the parliamentary elections is that the man's personality is stronger than a woman's personality.

2) Al-Dogmi Study (2007) entitled the quota system and its impact on Jordanian woman's political participation from 2003- 2006. This study aimed to identify the system of female quota applicable in the House of Representatives in 2003 and its impact on the political participation of Jordanian woman, and the results confirmed the impact of the quota system on Jordanian woman's political participation.

3) Al-Aqili Study (2005) political development in Jordan to examine the role of woman's political participation in Jordan, aimed to recognize the efforts being made at the international level and in Jordan to ensure the role of a woman in political life and to identify obstacles in woman's political participation, and the results indicated that in order to increase the empowerment of a woman by exercising her activities in the public sphere should enrich political development method, and activating the role of a woman and her activities, and that the government should enrich the Jordanian political development.

4) Ashour Study (2003) entitled the political participation of Jordanian woman in the parliamentary elections in the period between (1989 -2001) aimed to identify the forms of political participation of Jordanian woman and the goal of her participation in the parliamentary elections as voters and candidates, and the results were that the majority women leaders see that the experience of a woman in the elections is good and the researcher concluded that the majority of women leaders believe that the one-vote system prevents the election of a woman, and showed a range of factors limiting woman's access to parliament, notably tribal, and society's perception of woman's role and the lack of sufficient political experience, and lack of woman's interest in political matters, and that the most prominent solutions to promote political participation as voters and candidates, lies in supporting woman by woman and support of a woman by man and the integrity of the electoral process.

5) Rajeh Study (2003) entitled the political participation of Yemeni woman in political parties. The study aimed at identifying the Yemeni woman's participation in political life and the factors that it was actuated and to identify the impact of the political climate and the democratic and social and economic factors on woman's participation, the results showed that the Yemeni woman became more active in political life and parties, influenced by her desire to strengthen her self-confidence and her role in society, aided by the democratic climate and improve social and economic conditions and pluralism partisan, this was due to develop social, scientific, customs and traditions and community and family perception have a great role in her participation or reduce it.

6) Tahboub Study (2003) entitled the political participation of Jordanian woman during the nineties, aimed at identifying the difficulties and the factors influencing political participation in the nineties containing the most important stages of the electoral going on through Jordan. The researcher found that there are many factors that hamper and prevents woman's access to parliament, notably the Jordanian community culture factor, which is concentrated in the male patriarchal, tribal and cultural heritage that defines gender roles. The factors affecting the level of political participation of a woman affected in different forms and contribute these factors in shaping the size of political participation by citizens.

7) Naqshabandi Study (2001) entitled the political participation of a woman in Jordan and other Arab countries. This study aimed to address the relationship that affected the situation of Arab woman and her political participation in general and the factors influencing the development of Jordanian woman in particular, the researcher used the questionnaire and interview, and the results indicated that the higher the literacy rate for a woman increased her political participation, it also showed that there is no relationship between political participation and the status of work for a woman, It showed that whenever there is a help to a woman's care for her children, provided her with a greater opportunity for political participation.

8) Tall and Hammad Study(2000) entitled "Jordanian woman's participation in political action decision-making positions," aimed to identify the Jordanian woman's participation in parliamentary life and traditional authority, the results indicated the presence of weak participation of a woman in political action in state institutions and civil society institutions, and the lack of trends and activities satisfactorily between the ability of a woman in the 
areas of public action and control of a patriarchal society, and lack of recognition of the productive role of a woman.

9) Al-Sha'ri Study (2000), entitled trends events of the Faculty of Education at the University of Sanaa toward Yemeni woman's participation in political action. The study confirmed that if a woman has the opportunity for political participation she would be a successful politician, and the study reached that the Yemeni woman's political role is still weak, and also found that there are five variables play a role in influencing the role of Yemeni woman in politics and they are : religious variable, the social variable, political variable, economic variable, psychological variable, and political action requires action collectively and individually work to eliminate the negative effects and social customs and traditions that contrary to heavenly legislation and the constitution, and that woman's participation in politics is negative.

10) Tiltns Study (2000) entitled the Jordanian woman's participation in political and public life. The study showed the following results:

10.1 Regarding the voting it shows the following:

10.1.1 The proportion of older Jordanian who voted in the elections is more in percentage than younger.

10.1.2 There is no significant impact of education on the ballot.

10.1.3 Do not affect the status of a man in the ballot.

10.1.4 Percentage of the voting in the provinces is higher than in Amman.

10.1.5 The Palestinian refugees interests in voting is less attractive to the rest of the Jordanian citizens.

10.1.6 Those follow the news have a greater tendency to vote.

10.2 In terms of campaigning:

10.2.1 The greater the educational level of a woman, the more active in the campaign.

10.2.2 Women who have a larger share of movement freedom have a higher tendency to participate in election campaigns.

10.2.3 Live in households headed by a woman has a negative effect on woman's participation in electoral campaigns.

As shown by the results that there is no significant role to the level of income in the decision of people's attitudes about woman's participation in political life.

11) Middle East Marketing and Research Consultants Foundation Study (1997) en titled woman's participation in the 1997 parliamentary elections as voter and candidate, aimed to find out the most important reasons for granting vote for candidates in the parliamentary elections as well as to know the most important obstacles to woman's access to parliament and the study sample included (1432) individuals who participated in the 1997 parliamentary elections constituencies that were within the nominated woman and at least one, the sample was selected randomly, and the results indicated the following:

11.1 The reasons for granting the vote to candidate:

There are several factors in voters decision about the candidate and the most important was, a candidate from the same clan as answered voters of the sample were $28.5 \%$.

Good personal qualities enjoyed by the candidate $27 \%$, and came the services provided by or expected to be submitted by the candidate as a reason for giving a vote to the candidate in third place with $24.5 \%$.

As for the reasons for granting vote to a woman candidates has been observed that accounted for $61.5 \%$ of the sample has reported that outstanding personal qualities of the candidate is one of the most important reasons.

11.2 How much support for a woman candidate:

The study showed that the rate of $13,60 \%$ of the total respondents were more likely to elect a woman in the constituencies where the woman ran, but who have already elected a woman did not exceed $2.9 \%$.

11.3 Main reasons for the lack of woman's access to parliament:

The study showed that the most important reasons for the lack of woman's access to parliament are:

11.3.1 Society's perception of the role of a woman, who occupied the highest ratio of $30.8 \%$.

11.3.2 Tribal and misconception and the religious view of the member of parliament (woman) by $42.3 \%$.

11.3.3 lack of qualifications to be met by the candidate by $15.7 \%$. 
11.3.4 lack of the ability of the candidate to lead the campaign financially and morally by $7.10 \%$.

\subsubsection{Government manipulation of election results by $7 \%$.}

With regard to woman's ability to address public issues showed $35.8 \%$, and that the woman member of parliament have the same ability of the man (MP) $7.8 \%$.

The woman (MP) is more able than man (MP) in the treatment of public issues, while they view $50.9 \%$ that a woman (MP) less capable than man (MP) to address these issues.

12) Al-Salhi Study (1994) entitled "social obstacles to the participation of Jordanian woman in the field of political action" aimed to explore the social constraints of Jordanian woman's participation in political action, the researchers used a questionnaire to collect information, and reached to the conclusion that the existence of social constraints related to the outlook of the society to a woman as political leader, and that the man does not accept the political role of a woman and to be responsible for him.

13) Daghestani and Shteiwi study (1994) entitled Jordanian woman and political participation, the problem of the low political participation of a woman in Jordan through a field study, and the sample included (2050) quested, and the results indicated the following:

13.1 The Jordanian men and women still look to the role of a woman within the traditional gender expectations, as majority believes that the capacity of a woman in general is less than the capacity of man and particularly in political action.

13.2 woman can become a successful politician if given the opportunity and received the required support.

13.3 must be allocated a number of parliamentary seats for a woman.

13.4 large proportion of the respondents did not oppose the participation of a woman in political life.

13.5 There are constraints limit the capacity of woman's political participation, the most important among them is man's and society's opposition to the participation of a woman and not to encourage woman by woman, and the lack of motivation of the woman herself. Also the insufficient attention by the government, the parliament, and the parties to the integration of woman in political life.

13.6 There is a positive relationship between income and employment status, educational level and between the participation in political action.

14) Al-Azam Study (1991) on trends in selected sample of Jordanian society toward political participation to identify the view of the Jordanian society toward political participation and its relationship with some variables, as the researcher came to the conclusion that the interest in political participation was not a political value to the sample as it was to improve the economic and social situation through the provision of public services, and the researcher refer that to the nature of Jordanian society and its customs and upbringing social terms makes it imperative for individuals dependency on family and respect for parental authority, and for age, the older age the less political participation, and the greater the size of the family less political participation. As for education, more education, increased their political participation, but for the place of residence, those who live in big cities have more political participation than others, but sex is not to have much impact.

\subsection{Foreign Studies}

1) Akande Study (2007) entitled assessment of Middle Eastern politics for women in Parliament, woman has started all over the world access to the posts reserved for men, the results of the study indicated that the political participation can not be achieved without re-evaluate and change the recommendations, a review of the education system, the establishment of quota systems, and the institutionalization of regional imbalance.

2) Jarviz and others $(s, 2005)$ study was conducted by the Independence Office Research at the University of Texas at Austin, an exploratory study aimed to find out the intersection between education and employment and political participation, a sample of (1000) young people aged between (19-23) years, the study examined the political participation of young people from the three categories, students, working students, and non-students workers, and the results showed that working students have the highest level of political action and political skills, and political participation as compared to students only and workers, the study also found that students participating politically grew up in homes where there is political debate associated with participation on the basis of sex, and reached that woman's political participation is multidimensional.

3) Ross Study (1986) researcher carried out a survey of ninety societies to understand the social mechanism and the study find out that the effective political participation is more common in communities with a high degree of conflict and internal violence, and women participate effectively when prevail in society warm and approachable 
style, there are some social, economic, and cultural, variables and these play a role in exclusion of women directly or indirectly from all forms of participation in many societies.

4) Rojer and others study (1975) from Aiwa University conducted a study that the political parties play a significant impact in influencing the proportion of citizens' political participation, the researchers chosen sample of (290) citizen to determine the degree of citizen involvement of political personnel and the impact of social and economic sides of the effectiveness of the individuals political behavior, the analyzing of their answers has been shown that the strength of political party influence on their political participation is greater than the impact of social and economic factors.

5) Olsen Study (1977) on social participation and elections, in Indiana

On a sample of (750) individuals to determine the cause of the low percentage of participants in the elections in the United States, both presidential election or the election of members of the United States Congress and It shows that there is a statistically significant relationship between a set of demographic variables, such as race, age, religion, ethnicity and the percentage of participants in the elections, males more involved than females and blacks more involved than whites, and middle-older more participants than youth.

6) Jaros Study (1973) aimed to identify the differences between the sexes in political activity and political orientation, and believes that this is due to the early stages in the first years of life, males know the political information better than females and are more willing to change the political attitudes and there are differences between the sexes in political activity, according to the degree of woman's education and culture, have found significant differences between the sexes in particular in decisions related to the war and the use of force, and as a result of a tendency to issue more among females than males.

7) Poot Study (1972) for gender differences in political participation, found that the result has been strengthened on a global basis is that males are more active have more control, more aggressive less responsible and less expressive than females, researcher referred these differences to socialization females learn that their subordination to their husbands and fathers, and thus they are more negative and their less political participation.

\section{Method and Procedures}

\subsection{Methodology of the Study}

This study used the descriptive survey because it is the appropriate approach to this phenomenon which relate to human behavior or studying the trends of a society or a group of people. This approach also examines the polls for a group of people by adopting the descriptive survey approach.

\subsubsection{The Study Population}

The study population consists of Al-Balqa Applied University Students, who are in the academic year 2012/2013. Their total is (32160) male and female students.

The following table shows the distribution of the population of the study in different faculties of the University:

\begin{tabular}{lll}
\hline 1760 & Prince Ghazi College University & 1 \\
4200 & Planning College University & 2 \\
550 & Agriculture College University & 3 \\
302 & Al-Salt College University & 4 \\
1098 & Princess Rahma College University & 5 \\
3300 & Amman College University & 6 \\
3100 & Princess Alia College University & 7 \\
1600 & Engineer College University (Amman) & 8 \\
1250 & Al-Zarqa College University & 9 \\
750 & Aqba College University & 10 \\
1800 & Karak College University & 11 \\
3600 & Al-Husen College University & 12 \\
2150 & Irbid College University & 13 \\
1400 & Ajloun College University & 14 \\
5300 & Engineer College University (Irbid) & 15 \\
\hline 32160 & Total & \\
\hline
\end{tabular}




\subsubsection{Sample of the Study}

The study sample consisted of (1327) students from Al-Balqa' Applied University Students and they have been selected via stratified random sampling as it is shown in the following table

\begin{tabular}{lll}
\hline Total & Students & Number \\
\hline 589 & Male & 1 \\
738 & females & 2 \\
\hline
\end{tabular}

\subsubsection{Study Tool}

The researchers used the questionnaire as a the main tool to collect data and information, the questionnaire included (51) items

\subsubsection{Reliability of the Tool}

To make sure of the reliability of the tool it was presented to a group of arbitrators who are experts in this field . Their remarks were taken into consideration and necessary corrections were done.

\subsubsection{Stability Study Tool}

To ensure the stability of the tool, internal consistency was calculated by Cronbach's alpha equation, Table below shows these transactions . Resulted ratios considered appropriate for the purposes of this study.

Table 1. Internal consistency coefficient Cronbach alpha

\begin{tabular}{ll}
\hline & Internal Consistency \\
\hline Tool as a whole & 0.85 \\
\hline
\end{tabular}

As shown in table 1 the result separation was 0.85

\subsection{Results Separation}

Table 2 . The frequencies and percentages according to the study variables

\begin{tabular}{llll}
\hline Rate & Repetition & Categories & \\
\hline 44.4 & 589 & Male & \multirow{2}{*}{ Gender } \\
55.6 & 738 & Female & \\
\hline 42.7 & 566 & First Year & \\
31.3 & 415 & Second Year & Educational Level \\
12.6 & 167 & Third Year & \\
13.5 & 179 & Fourth Year & \\
\hline
\end{tabular}

\begin{tabular}{llll}
55.3 & 734 & Scientific & College Type \\
44.7 & 593 & Humanitarian & \\
\hline 32.1 & 426 & Countryside & \multirow{2}{*}{ Place of Residence } \\
67.9 & 901 & Urban & \\
\hline 100.0 & 1327 & Total & \\
\hline
\end{tabular}

The first question: "What are the trends of Al-Balqa Applied University students about woman's political participation in the parliamentary elections?"

To answer this question, arithmetic means and standard deviations of the trends of Al-Balqa' Applied University students about woman's participation in the parliamentary elections has been extracted, as shown in the table below. 
Table 3. Means and standard deviations of the trends of Al-Balqa' AppliedUniversity students toward woman's participation in the parliamentary elections in descending order

\begin{tabular}{|c|c|c|c|c|}
\hline $\begin{array}{l}\text { standard } \\
\text { deviation }\end{array}$ & $\begin{array}{l}\text { Arithmetic } \\
\text { means }\end{array}$ & Paragraphs & Number & Rank \\
\hline 1.02 & 4.25 & Woman better able to understand the status of a woman. & 15 & 1 \\
\hline 1.02 & 4.17 & Woman's participation in elections increases her self-confidence. & 38 & 2 \\
\hline 1.05 & 4.14 & I support election of a woman who has high education. & 39 & 3 \\
\hline 1.13 & 4.11 & Woman needs to be supported by women to reach political positions. & 28 & 4 \\
\hline 1.10 & 4.09 & Woman has better ability than man to support woman's rights. & 16 & 5 \\
\hline 1.11 & 4.07 & $\begin{array}{l}\text { I think that woman has the right to participate in parliamentary } \\
\text { election. }\end{array}$ & 20 & 6 \\
\hline 1.04 & 4.05 & Society trusts woman's ability. & 6 & 7 \\
\hline 1.05 & 4.04 & I think that the society gives woman the optimal role in politics. & 30 & 8 \\
\hline 1.17 & 4.04 & Participate in the parliamentary elections, is a right for the woman. & 35 & 9 \\
\hline 1.03 & 3.94 & The woman has a great interest in political issues. & 7 & 10 \\
\hline 1.10 & 3.93 & $\begin{array}{l}\text { woman's participation in parliamentary elections increases her rank in } \\
\text { the society. }\end{array}$ & 42 & 11 \\
\hline 1.12 & 3.92 & $\begin{array}{l}\text { woman's participation in the parliamentary elections attains her goals } \\
\text { and ambitions. }\end{array}$ & 44 & 12 \\
\hline 1.08 & 3.91 & $\begin{array}{l}\text { woman's participation in the parliamentary elections enables woman's } \\
\text { politically and socially. }\end{array}$ & 45 & 13 \\
\hline 1.17 & 3.89 & woman's has experience in political issues. & 1 & 14 \\
\hline 1.21 & 3.84 & woman has the ability to be a candidate. & 10 & 15 \\
\hline 1.20 & 3.84 & $\begin{array}{l}\text { woman needs to be supported by community members to reach } \\
\text { political positions. }\end{array}$ & 29 & 16 \\
\hline 1.09 & 3.84 & $\begin{array}{l}\text { woman can contribute to developing the society as member of } \\
\text { parliament. }\end{array}$ & 40 & 17 \\
\hline 1.08 & 3.83 & $\begin{array}{l}\text { The political participation helps a woman to be intellectually, socially } \\
\text { and economically independent. }\end{array}$ & 48 & 18 \\
\hline 1.18 & 3.82 & $\begin{array}{l}\text { Woman's participation in the parliamentary elections is not } \\
\text { compatible with her nature. }\end{array}$ & 36 & 19 \\
\hline 1.14 & 3.82 & $\begin{array}{l}\text { Woman's participation in the parliamentary elections makes her } \\
\text { respectable and admirable. }\end{array}$ & 49 & 20 \\
\hline 1.12 & 3.81 & $\begin{array}{l}\text { Woman's participation in the parliamentary elections helps her in } \\
\text { making critical decisions in public life. }\end{array}$ & 46 & 21 \\
\hline 1.13 & 3.79 & Woman has the ability to deal with political issues. & 8 & 22 \\
\hline 1.07 & 3.79 & $\begin{array}{l}\text { Woman supports her political and social rights as being a member of } \\
\text { parliament. }\end{array}$ & 12 & 23 \\
\hline 1.17 & 3.76 & Woman is able to exercise political action. & 3 & 24 \\
\hline 1.19 & 3.76 & $\begin{array}{l}\text { Participation in elections is a personal right for a woman and can use } \\
\text { it whenever she wants. }\end{array}$ & 43 & 25 \\
\hline 1.16 & 3.75 & I think woman can combine political work and family affairs. & 25 & 26 \\
\hline 1.20 & 3.74 & Woman has the ability to make decisions. & 5 & 27 \\
\hline
\end{tabular}




\begin{tabular}{|c|c|c|c|c|}
\hline 1.12 & 3.72 & Woman has a great role in parliamentary election. & 11 & 28 \\
\hline 1.21 & 3.72 & $\begin{array}{l}\text { Woman's participation in the parliamentary elections does not conflict } \\
\text { with the customs and traditions. }\end{array}$ & 37 & 29 \\
\hline 1.04 & 3.72 & $\begin{array}{l}\text { Woman participation in the elections contributes to enrich her } \\
\text { political energies. }\end{array}$ & 47 & 30 \\
\hline 1.27 & 3.71 & woman has a strong personality in political utterance. & 2 & 31 \\
\hline 1.29 & 3.61 & woman has the ability in political negotiations. & 4 & 32 \\
\hline 1.15 & 3.61 & $\begin{array}{l}\text { I think that our customs and traditions accepts woman's being a } \\
\text { member of parliament. }\end{array}$ & 32 & 33 \\
\hline 1.28 & 3.55 & I trust a woman who has a political positions in the society. & 51 & 34 \\
\hline 1.00 & 3.54 & $\begin{array}{l}\text { woman has the ability activate comprehensive social development as } \\
\text { being a member of parliament. }\end{array}$ & 17 & 35 \\
\hline 1.15 & 3.53 & $\begin{array}{l}\text { The absence of woman's participation underestimate comprehensive } \\
\text { social development. }\end{array}$ & 41 & 36 \\
\hline 1.12 & 3.49 & society can deal with a woman as a candidate. & 31 & 37 \\
\hline 1.05 & 3.45 & Woman has political competencies and potentials. & 13 & 38 \\
\hline 1.24 & 3.44 & society deals with a woman as one-half of society. & 24 & 39 \\
\hline 1.31 & 3.36 & $\begin{array}{l}\text { Society development needs the woman's participation in political } \\
\text { issues. }\end{array}$ & 22 & 40 \\
\hline 1.31 & 3.36 & $\begin{array}{l}\text { Woman plays an important role in the political life as she makes up } \\
\text { one half of society. }\end{array}$ & 18 & 41 \\
\hline 1.20 & 3.34 & woman proves success in political action. & 19 & 42 \\
\hline 1.43 & 3.32 & I support woman's involvement in all political issues. & 34 & 43 \\
\hline 1.26 & 3.31 & I support that woman being my representative in Parliament. & 33 & 44 \\
\hline 1.40 & 3.22 & Religion lets the woman to exercise the political life. & 9 & 45 \\
\hline 1.20 & 3.18 & woman completes man's role in all aspects of life. & 27 & 46 \\
\hline 1.47 & 3.15 & community sees a woman as having the political freedom. & 26 & 47 \\
\hline 1.13 & 3.12 & Woman has better ability than man to understand the social issues. & 14 & 48 \\
\hline 1.34 & 3.10 & $\begin{array}{l}\text { woman's participation in the parliamentary elections increases he } \\
\text { self-confidence. }\end{array}$ & 50 & 49 \\
\hline 1.44 & 3.07 & $\begin{array}{l}\text { Society sees woman as having political competencies and potentials } \\
\text { for political action. }\end{array}$ & 21 & 50 \\
\hline 1.52 & 3.06 & $\begin{array}{l}\text { Woman is well qualified physically and intellectually for political } \\
\text { participation. }\end{array}$ & 23 & 51 \\
\hline 41 & 3.68 & Whole & & \\
\hline
\end{tabular}

As shown in Table (3) that the arithmetic means ranged between (3.14 -4.05), as in paragraph (15), which reads " Woman better able to understand the status of a woman " in the first place and a means is (4.25), followed in second place paragraph (38), which reads "woman's participation in elections increases her self-confidence," a mean hit (4.17), followed in third place the paragraph (39), which reads "I support the election of a woman with high culture" a mean is (4.14), while paragraph (23), which reads, " Woman supports her political and social rights as being a member of parliament" rank last with means of (3.06). The arithmetic means of the tool as a whole is (3.68).

Second question: Are there significant differences at the level $(0.05=a)$ in the attitude of Al- Balqa Applied University Students about woman's participation in the parliamentary elections due to gender? 
To answer this question arithmetic means and standard deviations of the trends of Al-Balqa Applied University Students about woman's participation in parliamentary elections has been calculated, according to sex, and to indicate statistical differences between the arithmetic means "T" test was used as the table below shows.

Table 4. Means and standard deviations and "T" test depending on the sex variable trends of Al-Balqa Applied University students about woman's participation in parliamentary elections

\begin{tabular}{lllllll}
\hline $\begin{array}{l}\text { Statistical } \\
\text { significance }\end{array}$ & $\begin{array}{l}\text { Freedom } \\
\text { Degree }\end{array}$ & $\begin{array}{l}\mathrm{T} \\
\text { Value }\end{array}$ & $\begin{array}{l}\text { Standard } \\
\text { deviation }\end{array}$ & $\begin{array}{l}\text { Arithmetic } \\
\text { means }\end{array}$ & Number & Gender \\
\hline .000 & 1325 & -3.680 & .431 & 3.63 & 589 & Male \\
& & & .383 & 3.72 & 738 & Female \\
\hline
\end{tabular}

The table above indicates statistical differences at the level of $(0.05=a)$ attributed to gender and the differences attributed to females.

Third question: Are there significant differences at the level $(0.05=a)$ in the attitude of Al-Balqa Applied University students about woman's participation in the parliamentary elections due to educational level.?

To answer this question arithmetic means and standard deviations of the trends of Al-Balqa Applied University students about woman's participation in the parliamentary elections has been calculated due to the variable level of education, as the table below shows.

Table 5. Means and standard deviations of the trends of the Al-Balqa Applied University students towards woman's participation in the parliamentary elections due to the variable level of education

\begin{tabular}{llll}
\hline Standard deviation & Arithmetic means & Number & Categories \\
\hline .382 & 3.68 & 566 & First year \\
.410 & 3.66 & 415 & Second year \\
.415 & 3.65 & 167 & Third year \\
.462 & 3.75 & 179 & Fourth year \\
.407 & 3.68 & 1327 & Total \\
\hline
\end{tabular}

As shown inTable (5) variations ostensibly in arithmetic means and standard deviations of the trends of students of the Al-Balqa Applied University about woman's participation in the parliamentary elections were found because of different variable categories of educational level (first year, second year, third year, fourth year). To indicate the significance statistical differences between the arithmetic means ANOVA is used as table (6) shows.

Table 6. Analysis of the ANOVA impact on the attitudes of the educational level on trends of the Al-Balqa Applied University students towards woman's participation in parliamentary elections

\begin{tabular}{llllll}
\hline Statistical significance & P value & Average squares & degrees of freedom & sum of squares & Source \\
\hline .044 & 2.709 & .448 & 3 & 1.343 & Between \\
& & .165 & 1323 & 218.648 & Groups Within Groups \\
& & & 1326 & 219.991 & Total \\
\hline
\end{tabular}

Table 6 above reveals statistical differences at the level of $(0.05=a)$ attributed to the educational level, to illustrate the statistical differences and marital function between arithmetic means comparisons has been used by adopting shiva dimensional manner, as it shows in table 7 
Table 7. The impact of educational level on trends of the Al-Balqa Applied University students by Shiva way about woman's participation in parliamentary elections

\begin{tabular}{|c|c|c|c|c|c|}
\hline \multirow[t]{4}{*}{ fourth year } & third year & second year & first-year & $\begin{array}{l}\text { arithmetic means } \\
3.68\end{array}$ & $\begin{array}{l}\text { Educational level } \\
\text { first-year }\end{array}$ \\
\hline & & & .02 & 3.66 & second year \\
\hline & & .01 & .03 & 3.65 & third year \\
\hline & -.10 & $-.10(*)$ & -.08 & 3.75 & fourth year \\
\hline
\end{tabular}

* Function at the level of significance $(0.05=a)$

Table 7 indicates the significance statistical differences at the level of $(0.05=)$ are between the second year and the fourth year, and the differences came in favor of the fourth year.

Fourth Question: Are there statistically significant differences at the level $(0.05=a)$ in trends of the Al- Balqa Applied University Students towards woman's political participation in the parliamentary elections due to the type of college.?

To answer this question arithmetic means and standard deviations have been calculated .Regarding the trends of the Al-Balqa Applied University Students towards woman's political participation in the parliamentary elections depending on the type of college. To indicate the statistical differences between the arithmetic means "T" test, was used as shown in table below

Table 8. Means and standard deviations and "T" test variable depending on the type of college students trends of the of the Al-Balqa Applied University Students towards woman's participation in parliamentary elections

\begin{tabular}{lllllll}
\hline Statistical Significance & Freedom Degree & T Value & Standard Deviation & Arithmetic means & Number & College Type \\
\hline .050 & 1325 & 1.960 & .406 & 3.70 & 734 & Scientific \\
\hline & & .409 & 3.65 & 593 & Humanitarian \\
\hline
\end{tabular}

Table (8) indicates that there is no statistical significant differences at the level $(0.05=a)$ attributed to college type.

Fifth question: Are there significant differences at the level $(0.05=a)$ in trends of the Al- Balqa Applied University Students towards woman's participation in the parliamentary elections due to place of residence.?

To answer this question arithmetic means, standard deviations have been calculated .Trends of the Al-Balqa Applied University Students towards woman's participation in parliamentary elections, according to the place of residence, and to indicate statistical differences between the arithmetic means " $\mathrm{T}$ " test was used, as the table below shows.

Table 9. Means and standard deviations and "T" test depending on the variable place of residence on the trends of the Al-Balqa Applied University Students towards woman's participation in parliamentary elections

\begin{tabular}{lllllll}
\hline $\begin{array}{l}\text { Statistical } \\
\text { Significance }\end{array}$ & Freedom Degrees & T Value & Standard Deviation & Arithmetic Means & Number & Place of Residence \\
\hline .806 & 1325 & .246 & .412 & 3.68 & & \\
& & & .405 & 3.68 & 926 & Rural \\
\hline
\end{tabular}

Table (9) indicates that there is no significant differences at the level $(0.05=a)$ attributed to the Place of Residence.

\section{Results Discussion}

4.1 The discussion of the results relating to the first question: What are the trends of the Al-Balqa Applied University Students towards woman's political participation in the parliamentary elections? 
As shown in Table No. (3) The arithmetic means of the trends of the Al-Balqa Applied University Students on all the items of the questionnaire about political participation was $(3.68 \%)$ that is positive, and the researches attribute this result to social and the cultural change of the Jordanian society, resulting from the high level of education in Jordan and the evolution of the means of communication and openness to the world, which in turn makes a change in students' attitudes towards going out of the previously social conventional style of the Jordanian society, which is subject to the habits of the community and its traditions inherited from the control of clans thoughts and the misunderstanding of religious texts, also the media played a major role in changing people's attitudes about woman's political participation through correction to some religious concepts.

This comes in accordance with the study of Shteiwi and Daghestani, 1994) results of which showed that it is not opposed to woman's political participation.

As for the top-ranked paragraphs in the arithmetical means are as follows respectively:

1) The item that reads a woman better able to understand the status of a woman, researchers attribute for this item to the highest rank of the importance of a woman's role in understanding the status of a woman and man cannot understand the situation of woman as woman can understand woman .Thus students of the Al-Balqa University trends were about the presence of woman as deputy in the parliament because it is able to meet the needs of a woman and also can understand and defend her position.

2) The second item , which reads "woman's participation in elections increases her self-confidence" This item came in second place, perhaps because students' attitudes towards woman's participation in elections gives more confidence in herself, on the contrary, which is prevalent in the Jordanian society since it is masculine culture, and thus woman's participation in elections and success in that enhances a woman's more self-confidence, and out of the patriarchal culture of the community.

3) Ranked third ,item, which reads "I support the election of a woman who has high education and In students' attitudes towards political participation came in the third item, and perhaps researchers attribute this to the importance of culture and the role of a woman as participants in the political programs as the culture for a woman gives her the power of expression and opinion, and the ability to dialogue, and the researchers can refer also to the nature of the change in Jordanian society, as the Jordanian society is well educated, aware and conscious is reflected on the attitudes of the study sample to focus on the importance of education and culture for a woman as a political participants. This result agreed with the study of (Shteiwi and Dagestani, 1994) which indicated a relationship between education and political participation, also agreed with the study (Naqshbandi, 2001) higher education for a woman has increased her political participation. And disagreed with the study (Talitens, 2000), whose results indicated no significant impact of education in political participation. Perhaps this can be attributed to the different study population that affected the difference with this study.

4) In the fourth paragraph, which reads " Woman is well qualified physically and intellectually for political participation."

Perhaps researchers attribute trends of the Al-Balqa University students for this paragraph came in fourth place, because the woman now has become really qualified in terms of science, culture and knowledge and know her political rights, and her ability to political participation in more than one location, and she has proven to be successful in our Jordanian society in different locations, in the political parties, municipality mayor, frequently a member of parliament. This result agreed with the study of (Shteiwi, Dagestani, 1994) that a woman can become a successful politician if given the opportunity and disagreed with the study of (the Tal and Hammad, 2000) which indicated lack of recognition of the productive role of the woman and researchers can attribute this to the difference in the population of the study and it's sample.

4.2 Discussion the results relating to the second question: Are there significant differences in the trends of the Al-Balqa University students about political participation due to gender.?

As seen from the results referred to in table (4). There are significant differences in sex attributed in favor of females. Researchers assumed that it could be due to the fact that females are more sympathetic to their sex affection, and the trends of females with the participation of the woman in political life, contributing to enhance their self-confidence, and also because they are better able to understand their situation than men. This finding contradicted the study of (Azam, 1991) There are no differences of race and probably attributed to different society and the study sample, where Azzam's sample was of the Jordanian society in general while this study sample was of Al-BalqaUniversity students.

4.3 Discussion the results on the third question: Are there significant differences in the trends of the Al-Balqa University Students about the political participation of a woman is attributable to the scientific level.? 
The results referred to in the tables $(5,6,7)$ to the presence of significant statistical differences in scientific level attributable to the benefit of students of the fourth year.

Perhaps researchers attribute to the fact that fourth-year students are more aware and able to objectively determine their attitudes, as they are more mature and the ability to think critically of first-year students and the second year and third year.

4.4 Discussion results for the fourth question: Are there significant differences in the trends of the Al-Balqa University Students about the political participation of the woman is attributable to the type of college.?

Adopt the results referred to in the Table (8) and the absence of significant statistical differences attributed to the type of college, and possibly due to the common cultural pattern of the Al-Balqa University students as they are the sons of one community having the same joint value system, and have the same customs and traditions as they are the sons of a patriarchal society (paternal) who they can not get out of the ideas of this community in spite of the type of their scientific or humanitarian specialties.

4.5 Discuss the results of the fifth question: Are there significant statistical differences in the trends of the Al-Balqa Applied University students about the woman's political participation attributed to the place of residence.?

Seen from the results referred to in the Table (9) lack of statistically significant differences attributable to the place of residence between the countryside or the city.

researchers can attribute to the nature of homogeneity of Jordanian society, as the Jordanian society have a common culture, and there is no social, intellectual or class differences, also researchers can attribute this to the spread of the means of communication and the media as they approached between the sons of the same society and eliminated all of the differences between the countryside and the city and therefore there are no statistically significant differences between the countryside and the city. This result differed with (study Azam, 1991), which results indicated that those who live in big cities are more likely for political participation, can be attributed to the difference in the society of the study, from this study. Also conflicted with the study (Tiltns, 2000) which indicated that the votes in the provinces are more than in Amman, also could be due to differences in the study population.

\section{Recommendations}

According to the study's results the following recommendations are put forward:

Conduct further studies to include more sectors of Jordan in order to generalize the results. In addition, women issues are under studied by domestic and foreign researchers, except UN reports, consequently more women studies are needed in Jordan.

Recommendations:

1) To activate the role of the woman in political participation through the media.

2) To work on activating the role of civil society organizations in political participation.

3) To work on changing society's perception for a woman through the change of culture related views in the community.

4) To encourage woman to take part in political participation through the family, the clan and the university institutions.

5) To highlight the woman's role in the development of society through the curriculum, university seminars, and through integration in to the students activities.

6) To work on strengthening partisan life in Jordan and open the way for the woman to participate more in the political process.

7) That the government allocates a fixed quota seats in the House of Representatives for a woman.

\section{References}

Akande, A.-K. (n.d.). The Evolution of Woman in Middle Eastern Politics, Opportunities for woman in parliament, unpublished Master thesis, the Fletcher school, USA.

Al-Anzi, S. G. (2008). Jordanian woman's political participation in political action from 1952-2006, unpublished Master thesis, University of Jordan, P 57.

Aldogmi, D. M. (2007). The quota system and its impact on political participation of Jordanian woman from 
2003- 2009, unpublished Master Thesis, Al -Bayt University. pp 150-160.

Almond, G. (1971). The Politics of Developing Area. PrincetonUniversity Press, Princeton.

Almond, G., \& Verba. (1965). The Civic Culture. Little Brown, Boston.

Al-Shar'I, A. A. (2000). Trends events of the Faculty of Education at the University of Sanaa toward Yemeni woman's participation in political action. Yemen pbublishing House.

Aqili, M. A. (2005). Political development in Jordan, a study on the role of woman in Political participation. Cairo University Journal, V(1), 25-30.

Ashour, E. M. (2003). Jordanian Woman's political participation (1989- 2001) Unpublished Master's Thesis, the Jordan Institute of Diplomacy, Graduate Studies.

Azam, A. M. A. (1991). Trends selected sample from the Jordanian society, political participation, field study. Journal of Studies, 18(2), 175.

Jarvis, S. et al. (2005). The Political Participation of Working Youth and College Students. University of Texas, Austin.

Lipest, S. (1973). Political Man. Heinemann, London.

Naqshabandi, B. (2001). Woman's political participation in Jordan and other Arab countries, volume 1, Al-Faris Publishing House, Amman.

Olsen, E. M. (1977). Social Participation and Voting Turnout. American Sociological Review, 37, 69. https://doi.org/10.2307/2093471

Pro, Philip. (1998). Political Sociology Science, Mohammad translated by Mohammad ArabiMamilla, the Arab Studies and Publishing institution, Beirut.

Rajeh, K. A.- K. (2003). Political participation of Yemeni woman in political parties, unpublished Master Thesis, University of Jordan, Amman.

Rojers, L. D. et al. (1975). Voluntary Association membership and Political Participation. USA.

Rush, M. (2005). Politics and Society. Prentice Hall, New York.

Saleh, N. et al. (1997). Political culture, the Democratic philosophical institution Studies. Ramallah, Palestine.

Salhi, S. (1994). Social Constraints of Jordanian Woman's Participation in Political Action, field study in Amman, unpublished Master Thesis, University of Jordan. pp 59-63.

Shteiwi, D. (1994). The Jordanian Woman and the political participation. Al-Ithad publishing house, Amman.

Tahboub, A. (2003). Jordanian Woman's political participation during the nineties, Unpublished Master Thesis, University of Jordan, Amman.

Tall, \& Hammad. (2000). The Jordanian Woman and the participation in political action, decision making positions, Jordan.

Tiltns, O. (2000). Jordanian woman's participation in political and public life, edited by Hussein Abu Rumman, Sinbad Publishing House, Amman.

\section{Copyrights}

Copyright for this article is retained by the author(s), with first publication rights granted to the journal.

This is an open-access article distributed under the terms and conditions of the Creative Commons Attribution license (http://creativecommons.org/licenses/by/4.0/). 